\title{
Mat leikskólabarna á pátttöku í tilviksrannsókn
}

\author{
Anna Elísa Hreiðarsdóttir og Kristín Dýrfjörð
}

$\checkmark$ Abstract Um höfundana $>$ About the authors $>$ Heimildir

Greinin fjallar um mat og pátttöku leikskólabarna í rannsókn um sköpunarsmiðjur í leikskólanum peirra og var tilgangurinn að rýna í hvernig börn upplifðu pátttöku í rannsókninni. Bakgrunnur rannsóknarinnar byggir á ákvæði í Barnasáttmála Sameinuðu pjóðanna um pátttöku barna. Gagna var aflað í mars (smiðjur) og júní (rýniviðtal) 2018. Níu fimm ára börn voru pátttakendur í sex vinnusmiðjum par sem leikið var með stafræn tæki, legokubba og annan skapandi efnivið. Meðan á smiðjum stóð söfnuðu rannsakendur gögnum með fjölbreyttum hætti, svo sem með myndbandsupptökuvél og myndavél og héldu dagbækur, börnin öfluðu gagna með smámyndavél (GoPro), spjaldtölvu, fylltu út matsblað eftir hverja smiðju og rýniviðtal var tekið við pau eftir að smiðjum lauk. Í greininni eru matsblöð barnanna, dagbækur rannsakenda og rýniviðtal við börnin lögð til grundvallar niðurstöðum.

Helstu niðurstöður sýna að börn eru verðugir pátttakendur í rannsókn og að sjónarhorn peirra varpar nýju ljósi á gögnin í rannsókninni. Fram kom að börnin virtust vera ánægðust með pau verkefni sem pau höfðu sjálf vald yfir, hvort sem pað sneri að sköpun eða tækjabúnaði, pannig heillaði smámyndavélin sem pau stýrðu sjálf, litlu stafrænu tækin og að taka viðtöl hvert við annað með spjaldtölvu. Hins vegar er vert að benda á að einn af peim páttum sem kom fram í niðurstöðum er að sum barnanna upplifðu viðveru rannsakenda í smiðjum stundum truflandi. Dað er vert fyrir rannsakendur sem vinna rannsóknir með börnum að hafa hugfast.

Efnisorð: Dátttökurannsóknir, leikskólabörn, rödd barna

\section{Inngangur}

Til langs tíma hefur sýn barna verið vaxandi viðfangsefni bæði fræðafólks og löggjafa. Degar litið er yfir próun alpjóðlegra sáttmála og innlendra laga má sjá síaukinn punga í pá átt að tryggja börnum réttindi og aðkomu að eigin málum. Sérstaða barna sem sérstaks menningarlegs hóps var viðurkennd með Genfaryfirlýsingu Djóðabandalagsins árið 1924 en hún var ekki bindandi fyrir pjóðirnar sem að henni stóðu fremur en yfirlýsing Sameinuðu pjóðanna frá árinu 1959. Næsta skref var stigið pegar Barnasáttmáli Sameinuðu bjóðanna ${ }^{1}$ (Samningur Sameinuðu pjóðanna um réttindi barnsins, 1992) var sampykktur á Allsherjarpingi Sameinuðu pjóðanna 20. nóvember árið 1989. Ísland gerðist aðili að honum ári síðar og var hann fullgiltur árið 1992 en ekki lögfestur fyrr en árið 2013 (Lög um samning Sameinuðu pjóðanna um réttindi barnsins nr. 19/2013). Í Barnasáttmálanum er ákvæði í 12. grein um rétt barna til að mynda og láta skoðanir sínar í ljós í öllum peim málum sem pau varðar í samræmi við aldur peirra og proska. Með pví

\footnotetext{
Hér eftir nefndur Barnasáttmálinn
} 
að gerast aðili að Barnasáttmálanum tóku íslensk stjórnvöld á sig ýmsar skyldur sem purfti að raungera m.a. með lagabreytingum. Meðal mikilvægra lagabreytinga er ákvæði frá 1995 sem var bætt við stjórnarskrána um lagavernd til handa börnum sem snýr að velferð peirra, vernd og umönnun (Stjórnarskrá lýðveldisins Íslands nr. 33/1944), pessar lagabreytingar höfðu svo áhrif á Aðalnámskrá leikskóla (Menntamálaráðuneytið, 1999; Mennta- og menningarmálaráðuneytið, 2011) par sem skýr ákvæði eru um pátttöku barna.

Kjarninn í Barnasáttmálanum er að hagsmunir barna séu hafðir að leiðarljósi. Eignarhald á bernskunni og börnum er ekki í höndum foreldra eða stjórnvalda heldur eru börn sjálfstæðir einstaklingar með frelsi til sjálfstæðra skoðana og vilja. Dví ber að leita eftir peirra sjónarhorni í málum er pau varða. Réttindi Barnasáttmálans ná til fjögurra pátta; réttinn til lífs, réttinn til að proskast og læra, réttinn til pátttöku og réttinn til verndar. Sá hluti sem snýr að réttinum til pátttöku felur í sér viðurkenningu á að börnum sé gefinn möguleiki á að taka pátt í samfélaginu, peim sé gert kleift að láta skoðanir sínar í ljós, pær séu virtar og á pær hlustað. Pau hafi réttindi til að segja til um málefni sem að peim snúa og koma lífi peirra við (12. og 13. grein). Í Barnasáttmálanum er dregin fram pörf barna fyrir sérstaka vernd, sérstaka aðstoð við að hafa rödd og sérstaka meðhöndlun vegna aldurs og valdleysis. Barnasáttmálinn markaði tímamót og greiddi baráttu fyrir réttindum barna leið. Með tilkomu hans breyttist viðhorf til barna frá pví að líta á pau sem hluta af fjölskyldu eða eign foreldra sinna í að sjá pau sem einstaklinga með sjálfstæðan rétt. Pátttaka barna er talin efla borgaravitund peirra og pátttöku peirra í samfélaginu, jafnvel til langframa. Pascal og Bertram (2009) vara við að áherslan sé fyrst og fremst á framtíðina og að barnið verði fær fullorðinn einstaklingur. Dau benda á að horfa purfi til pess sem barnið er hér og nú og pann ávinning sem barnið hefur af pví að vera virkur pátttakandi í lýðræðislegu samfélagi. Breytingar á viðhorfum til barna sem virkra pátttakenda hafa einnig haft áhrif á hvernig litið er á börn í rannsóknum.

Bernskan hefur lengi verið hugðarefni fræðimanna og framan af mótuðust hugmyndir um bernskuna án pess að raddir barna kæmu par að. Lengst af voru börn pögull hópur eða kannski mætti heldur segja paggaður hópur (MacBlain, Dunn og Luke, 2017). Litið var á börn sem manneskjur í mótun og pau pví ófullkomin og vanmáttug (Mukherji og Albon, 2010). Levy og Thompson (2015) benda á að pað eitt að vera án reynslu er ekki nægileg ástæða til að líta svo á að börn séu ekki sérfræðingar í eigin lífi pví hið sama eigi við fullorðna, enginn sé í raun fullmótaður sem persóna. Dví sé reynsluleysi barna ekki næg ástæða til að útiloka pau frá virkri pátttöku í rannsóknum um málefni sem pau varða. Hér eru færð rök fyrir pví að börn geti haft sitt til málanna að leggja í rannsóknum, ekki einungis sem viðfangsefni heldur pátttakendur.

Til langs tíma voru börn allt að pví hlutgerð í rannsóknum, pau voru jaðarsett í eigin heimi. Dæmi um petta má sjá í fræðigreinum par sem talað er um að gera rannsóknir á börnum en ekki með börnum, jafnvel rannsóknir par sem pau voru virkir pátttakendur. Ljóst er að börn hafa lítil áhrif og takmarkað vald og eru par af leiðandi jaðarhópur í samfélagi par sem völdin og áhrifin liggja hjá hinum fullorðnu (Guðrún Alda Harðardóttir, 2014). Með tilkomu Barnasáttmálans breyttist petta viðhorf smám saman og umræða um pátttöku barna í rannsóknum fór að heyrast. Nú er svo komið að pað pykir bæði sjálfsagt og eðlilegt að pau séu virkir pátttakendur í rannsóknum og horft sé á styrkleika peirra og getu (Jóhanna Einarsdóttir, 2012a).

Rannsóknin sem hér er sagt frá er hluti af alpjóðlega rannsóknarverkefninu MakEY (e. Makerspaces in the Early Years: Enhancing Digital Literacy and Creativity, http://makeyproject. eu) sem unnið er með Marie Skłodowska-Curie styrk. Eitt meginmarkmið MakEY-verkefnisins er að skoða hvernig megi stuðla að stafrænu læsi ungra barna, sköpun og hönnunarhugsun í sköpunarsmiðjum (e. makerspace). Sköpunarsmiðja felur í sér að útbúa aðstæður par sem tækifæri til sköpunar eru mörg og par sem leitast er við að vinna með nýjustu tækni og hugmyndir í bland við eldri aðferðir. Sá hluti rannsóknarinnar sem hér er fjallað um fól í sér að skoða pátttöku níu fimm ára barna í sex vinnusmiðjum par sem hugmyndafræði og aðferðir sköpunarsmiðja voru nýttar til að búa til námsumhverfi. Börnin unnu með stafræna tækni og grundvallaratriði 
forritunar í gegnum leik, sköpun og sögugerð. Markmið greinarinnar er að skoða eigin upplifun barnanna af pátttöku í rannsókninni, fjallað er um pann hluta gagna sem sneri að mati barnanna á pátttöku í smiðjunum, rýniviðtal við börnin eftir að smiðjum lauk og dagbækur rannsakenda.

\section{Pátttaka barna í rannsóknum}

Rannsóknum með pátttöku barna hefur fjölgað undanfarna áratugi (Clark, 2011) og pær spanna vítt svið. Rætur peirra liggja innan ólíkra greina eins og mannfræði, sálfræði, læknisfræði og félagsfræði svo dæmi séu tekin. MacBlain, Dunn og Luke (2017) minna pó á að stöðluð bernska er ekki raunverulegt fyrirbæri og bernskan er ekki ein upplifun heldur eru pær fjölmargar, meðal annars tengdar samfélagi, menningu og félagslegum páttum. Hvert barn er barn síns tíma og peirrar menningar og bakgrunns sem pað tilheyrir. Bradwell og félagar (2011) segja ein mestu áhrifin sem pátttaka barna í rannsóknum hefur sé að efla pekkingu á bernskunni og skilning á veröld barna. Dahlberg, Moss og Pence (2006) telja siðferðilegar og heimspekilegar stoðir fyrir pví að hverfa frá fyrri viðhorfum sem gera ráð fyrir að börn séu varnarlaus og lítils megnug og sjá pau pess í stað sem hagsmunaaðila í eigin lífi. Börn séu megnugir einstaklingar og geti tekið upplýstar ákvarðanir. Degar röddum barna er gefinn gaumur getur pað verið áskorun á fyrri ályktanir og jafnvel gefið óvænta innsýn í færni barna og möguleika. Pascal og Bertram (2009) segja að pannig geti skilningur hinna fullorðnu aukist á hvað er börnunum mikilvægt, hvar áhugi peirra liggur og hvernig pau upplifa sig sjálf og eigið líf.

Bolzan og Gale (2011) telja að viðhorf til barna í rannsóknum hafi lengstum verið litað af hugmyndum um að börn séu vanmegnug og geti ekki gert hluti á sama hátt veg og fullorðnir. Hinn fullorðni verði pví að læra og próa nýja tækni og aðferðir til að komast nær sjónarmiðum barnanna. Hann eigi hins vegar til að hunsa eða gera lítið úr vísbendingum um að börnin ráði við aðstæður. Dar með, prátt fyrir góðan ásetning, geti rannsakendur verið blindir á pað sem börnin hafa fram að færa. Í rannsókn Alaca, Rocca og Maggi (2016) sýna niðurstöður að ung börn séu fær um að eiga árangursrík og fjölbreytt samtöl um samfélagið sem pau lifa í. Dær telja að sjónarmiðum barna megi ná fram í margs konar rannsóknum en í mismiklum mæli pó. Nilsson o.fl. (2013) benda á að pað er munur á pví að leita eftir sjónarmiðum barna eða að gefa sér pau. Par liggur munurinn í hugmyndum um rannsóknir á börnum eða rannsóknir með börnum. Rannsóknir sem börn leiða (e. child led research) eru enn ein leið og er tilgangur peirra að efla börn sem virka rannsakendur. Með stuðningi fullorðinna er peim gert kleift að rannsaka efni sem eru peim sjálfum mikilvæg. Sú hugmyndafræði byggir á viðhorfum um að börn séu sérfræðingar í eigin lífi (Kellett, 2011). Dátttaka getur styrkt börnin og gefið peim verkfæri til að efla eigið nám og proska, hvatt pau til að taka ákvarðanir, tjá skoðanir sínar og hugmyndir og par með byggja upp jákvæða sjálfsmynd (Pascal og Bertram, 2009) en börn purfa reynslu í að vera pátttakendur (Aubrey, Blackburn, Jones og Lowe, 2017), með öðrum orðum purfa pau æfingu í að vera virkir pátttakendur.

Barnasáttmálinn og pau áhrif sem hann hefur haft á lög um réttindi barna og siðfræði rannsókna hefur leitt af sér að varnarveggir hafa verið reistir í kringum börn sem meðal annars hefur takmarkað aðgengi rannsakenda að peim og veröld peirra. Lundy og McEvoy (2012) telja að hliðverðir (e. gatekeepers) barna taki gjarnan ákvarðanir fyrir hönd peirra án samráðs við pau. Aubrey, Blackburn, Jones og Lowe (2017) hafa dregið saman rannsóknir víða að úr heiminum og segja að pegar börn séu með í ráðum eigi hinir fullorðnu til að hlífa peim við ákveðnum málefnum eða taka ákvarðanir um hvað sé peim fyrir bestu, enda er pað skylda hinna fullorðnu að vernda rétt barna. Guðrún Kristinsdóttir og Hervör Alma Árnadóttir (2015) gerðu rannsókn á hlutverki barna í rannsóknum hérlendis. Niðurstöður peirra benda til pess að einfalda purfi og skýra ferli formlegra leyfa. Pær segja að fagmenn séu oft tregir til pess að opna hlið fyrir rannsakendur pó svo að formleg leyfi liggi fyrir. Hæfni rannsakenda til pess að ræða við börn og pekking á börnum og aðstæðum peirra eru á meðal pess sem pær telja skipta máli við rannsóknir með börnum. Pær kalla eftir aukinni meðvitund um áhrif og hlutverk hliðvarða. 
Рað getur verið ávinningur fyrir börn að taka pátt í rannsóknum. Lundy og McEvoy (2012) segja að pátttaka geti haft jákvæð áhrif á sjálfstraust barna. Anna Magnea Hreinsdóttir (2012) bendir á að pátttökurannsóknir geti virkað eflandi fyrir börn ef viðeigandi aðferðum er beitt. Undir slíkt sjónarmið tekur Wright (2015) sem segir að pátttaka geti jafnframt gefið börnum svigrúm til að rannsaka á eigin forsendum.

\section{Álitamál}

Breytingar á viðhorfum til barna í kjölfar Barnasáttmálans hafa eins áđur segir opnað fyrir nýjar leiðir í rannsóknum og leitt til aukinnar áherslu á pátttöku barna. Rannsóknir með börnum vekja upp mikilvægar spurningar tengdar siðfræði annars vegar og valdi hins vegar (Waller og Bitou, 2011). Siðfræði og vald eru sampætt viðfangsefni í rannsóknum með börnum og parf að skoða í ljósi laga og reglugerða, til dæmis varðandi réttindi barna til að eiga aðild að ákvörðunum sem skipta pau máli, svo sem pátttöku í rannsóknum. Lundy og McEvoy (2012) telja að pátttaka barna kalli á ígrundaða afstöðu til réttinda peirra. Hafa purfi í huga atriði eins og öryggi barnanna, pátttöku peirra og tækifæri til að tjá skoðanir sínar. Rogers, Labadie og Pole (2016) telja að prennt purfi að hafa í huga í rannsóknum með börnum, nota purfi pátttökumiðaða aðferðafræði, líta purfi á sampykki sem ferli sem er í sífelldri endurskoðun á meðan á rannsókninni stendur og standa purfi sérstakan vörð um persónueinkenni barnanna.

Dockett og Perry (2011) hafa bent á að pað geti verið tiltekinn pröskuldur í rannsóknum að rannsakendum ber lagaleg skylda til að leita sampykkis foreldra og annarra hliðvarða barnanna fyrir pátttöku peirra í rannsóknum. Ferlið geti verið langt og flókið. Samkvæmt Moore, Saunders og McArthur (2011) eru hliðverðir barnanna ein stærsta hindrunin sem rannsakendur mæta pegar leitað er eftir aðgengi að börnum til samstarfs í rannsóknum. Deir taka hlutverk sitt alvarlega og finnst pað skylda sín að taka ákvarðanir fyrir hönd barnanna, mögulega til að hlífa peim eða verja í einhverju samhengi. Hlutverk rannsakanda er að gæta pess að hafa hag barnanna að leiðarljósi, virða einkalíf peirra og tilfinningar (Palaiologou, 2016). Forvitinn fullorðinn getur auðveldlega stigið yfir línuna sem afmarkar persónu eða einkalíf barna og parf að sýna varfærni (Chadwick og Webster, 2010). Í pessu ljósi má velta fyrir sér hlutverki fullorðinna í rannsóknum. Dað er fín lína sem rannsakandinn dansar á pegar hann parf að vera til staðar svo börnin upplifi áhuga og virðingu hans án pess að vera til dæmis uppáprengjandi eða virðast áhugalaus.

Tvenns konar viðhorf finnast í rannsóknum með börnum, annars vegar að nota megi sömu aðferðir og í rannsóknum með fullorðnum og hins vegar að beita purfi aðferðum sem eru barnmiðaðar. Eru rökin pá að ekki megi horfa fram hjá valdaójafnvægi milli barna og fullorðinna (Jóhanna Einarsdóttir, 2012a). Sumar aðferðir til gagnaöflunar eru taldar henta pátttöku ungra barna verr, svo sem einkaviðtöl eða spurningalistar. Er pað vegna pess að pær eru taldar geta dregið úr valdi barnanna og leitt af sér vanmat á getu peirra sem mætti koma í veg fyrir með viðeigandi rannsóknaraðferðum (Chadwick og Webster, 2010). Fleiri lykilpættir skipta máli, svo sem að aðferðir purfa að hæfa aldri og proska barnanna og viðfangsefnið verður að hafa merkingu fyrir pau. Að sama skapi hentar betur að vinna rannsóknir á og með börnum í leikumhverfi peirra í stað pess að setja pau í ókunnugar aðstæður (Mukherji og Albon, 2010). Rannsóknir með börnum eru hvorki einfaldar né án vandkvæða og pannig má ekki gera ráð fyrir að aðferðafræðin efli sjálfkrafa pátttöku barnanna, rannsóknarsnið og samskipti eru lykilatriði fyrir virkri pátttöku peirra (Waller og Bitou, 2011).

Kim (2016) segir einn vanda sem fylgir pátttökurannsóknum pann að pær eru gjarnan hugsaðar út frá sjónarhóli fullorðinna og markmiðum peirra fremur en barnanna. Lenz Taguchi (2010) bendir einnig á að pað sem fullorðnir velji að skoða sé í raun valdatæki, jafnvel til að stýra börnum undir pví yfirskini að pau hafi verið pátttakendur. Túlkun á sjónarhorni barna er síðan gjarnan frá sjónarhóli fullorðinna (Waller og Bitou, 2011) og ekki endilega víst að túlkunin sé í takt við pað sem börnin áttu í raun við (Palaiologou, 2014). Jóhanna Einarsdóttir (2012a) segir pann sem vinnur að rannsóknum með börnum purfa að huga að viðhorfum sínum og sannfæringu 
hvað varðar börn, hæfni, réttindi peirra og hlutverk í rannsóknum. Spyrou (2011) minnir á að gefa purfi meiri gaum að jafnvægi og valdi pegar börn og fullorðnir vinna saman í rannsóknum pví undirliggjandi sé ójafnvægi sem stundum geti átt sér vel faldar hliðar. Рað skiptir máli að rannsakandi átti sig á pví valdi sem hann hefur, varist að setja sinn eigin merkimiða og væntingar á pað sem börnin hafa fram að færa og sé varfærinn í túlkun gagna.

Rannsóknir með börnum krefjast pess í grundvallaratriðum að börnin séu tilbúin í samstarf og að ná pví fram er ekki einfalt í framkvæmd. Skýr sýn og góður undirbúningur er mikilvægur til að tryggja að verkefnið sé eins barnmiðað og hægt er (Yardley, 2011). Börn eru fjölbreyttur hópur og fleira hefur áhrif en augljósir pættir svo sem aldur. Dannig skiptir félagsleg staða, kyn, menning og heilsa máli svo dæmi séu tekin og pað er varasamt að ætla að börn séu alls staðar eins (Mukherji og Albon, 2010). Albon og Barley (2018) minna á að börn purfa og parfnast ólíkra upplýsinga um rannsóknina sem um ræðir. Dví purfi að muna að pegar leitað er eftir pátttöku ungra barna pá hentar ein leið ekki öllum.

Aukinn áhugi rannsakenda á að fá fram sjónarmið barna og reynslu, hefur haft í för með sér nýjar rannsóknaraðferðir, meðal annars aukna notkun sjónrænna miðla eins og ljósmynda og kvikmynda (Jóhanna Einarsdóttir, 2008; Lipponen, Rajala, Hilppö og Paananen, 2016). Änggård (2015) lýsir hvernig börn taka ljósmyndir sem gefur peim leið til að kanna viðfangsefni og setur pau í hlutverk rannsakandans. Cook og Hess (2007) taka undir petta og segja að pegar börn taki myndir sé líklegt að pau velji að mynda pað sem veki áhuga peirra og pessi leið nýtist einkar vel ef viðfangsefnið er huglægt. Баð er ljóst að vanda parf til rannsókna með börnum og ábyrgð rannsakandans er mikil.

\section{Aðferð}

Rannsóknin er tilviksrannsókn unnin með pátttöku barna og er hluti af evrópsku rannsókninni Makerspaces in the early years: Enhancing digital literacy and creativity. Sá hluti sem hér um ræðir ber heitið Makerspaces in preschools: Preschool children learning about and with digital technology in creative and playful manner og er einn páttur í íslenska hluta rannsóknarinnar. Deir sem að honum standa eru Anna Elísa Hreiðarsdóttir, Kristín Dýrfjörð og Margrét Elísabet Ólafsdóttir. Hér er fjallað um gögn sem sneru að pátttöku barna í mati á smiðjum og rýniviðtali við börnin eftir að verkefni lauk en einnig eru dagbækur rannsakenda notaðar til að styrkja niðurstöður.

\section{Framkvæmd rannsóknar og úrvinnsla gagna}

Dátttakendur í rannsókninni voru níu börn í völdum leikskóla, leikskólakennarinn peirra og leikskólakennaranemi í meistaranámi. Börnin tóku pátt í smiðjum sem fóru fram tvisvar í viku yfir priggja vikna tímabil í leikskólaumhverfi barnanna og hver smiðja var að jafnaði ein til ein og hálf klukkustund. Barnahópurinn samanstóð af fjórum stúlkum og fimm drengjum og valdi kennari börn í hópinn með раð að leiðarljósi að hafa hópinn eins fjölbreyttan og mögulegt var og að kynjahlutfall væri sem jafnast.

Rannsakendur skiptust á að vera viðstaddir smiðjur, einn í hverri smiðju. Hlutverk peirra var að setja upp rannsóknartækin, fylgjast með, skrifa dagbækur, taka ljósmyndir og ganga frá í lokin. Rannsakendum var ætlað að vera áhorfendur en eins og kemur fram hjá Hrönn Pálmadóttur og Jóhönnu Einarsdóttur (2015) eiga börn til að reyna að draga rannsakandann inn í leik og pau kalla eftir athygli, sérstaklega ef hún er ekki til staðar frá kennurum pá stundina. Dær segja að börn geti upplifað rannsakendur bæði sem styðjandi og truflandi. Раð eru atriði sem ber að hafa í huga og rannsakendur voru meðvitaðir um. Upptökuvél var sett á prífót við útjaðar leiksvæðis barnanna og tók hún upp pað sem fram fór meðan á smiðjum stóð. Börnin höfðu aðgang að smámyndavél (GoPro) og höfðu val um að nota og festa á sig í bringufestingu en tilgangurinn 
með vélinni var að sjá viðfangsefnið út frá sjónarhóli barnanna. Rannsakendur settu einnig upp aðstöðu í einu horni rýmisins par sem spjaldtölva var fest á arm og útbúin aðstaða par sem börnin gátu tekið viðtöl hvert við annað. Detta kölluðu pau fréttahornið. Í smiðjum unnu börnin með stafræna kubba og forritanlega vélveru sem nefnd var Mæja. Skapandi nálgun, sögugerð og leikur var hluti af viðfangsefnum smiðja.

Gögnin sem liggja að baki pessari rannsókn eru prípætt, 1) matsblöð og viðtöl við börn við lok hverrar smiðju, 2) rýniviðtal við barnahópinn og að síðustu 3) dagbækur rannsakenda. Smiðjur fóru fram í mars 2018 en rýniviðtal var tekið í júní sama ár.

Vinnan í smiðjum fólst í að börnin hönnuðu og teiknuðu sögupersónur og sögusvið, pau léku og lærðu á stafræn tæki, Mæju og stafræna kubba sem hægt var að tengja við legokubba. Í lok hverrar smiðju fylltu börnin út matsblað. Á blaðinu merktu börnin við tilfinningatákn eins og sjá má á mynd 1. Petta gerðu pau einstaklingslega og í kjölfarið ræddi kennarinn við pau hvert og eitt um matið og pað sem að baki pví lá. Hann skráđi orð barnanna og útskýringar inn á sama matsblað.

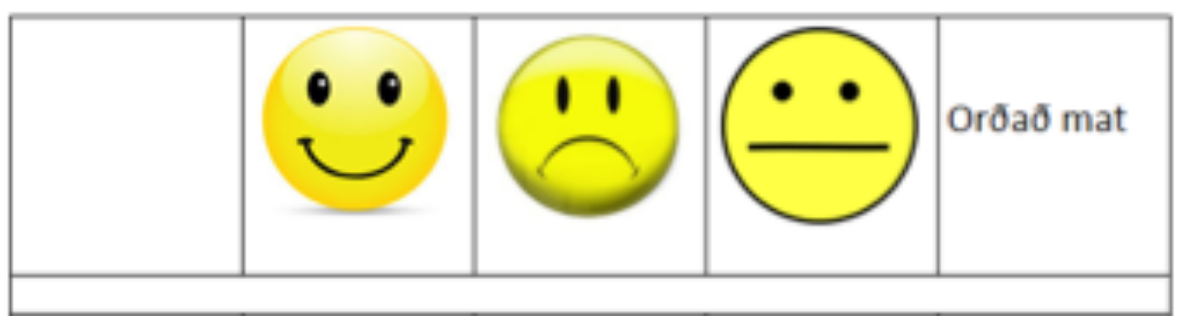

Mynd 1. Sýnishorn af matsblaði barna

Matsblöðin voru greind á pann hátt að fyrst voru táknin talin og tengd viðfangsefnum og smiðjum, pær niðurstöður voru síðan skoðaðar í samhengi við pað sem fram kom í viðtölum barna við kennarann. Næst var rýnt í hvernig börnin notuðu táknin í samhengi við pað sem fram kom í viðtali kennarans við pau. Niðurstöður voru greindar út frá einstaka smiðjum og hverju barni fyrir sig. Samkvæmt Fane, MacDougall, Jovanovic, Redmond og Gibbs (2018) geta tilfinningatákn fært völd frá rannsakendum til barna og dregið úr áhrifum fullorðinna í rannsóknarferlinu. Pau telja notkun á táknum geta gefið börnum ákveðna stjórn á eigin pátttöku í rannsóknum.

Rannsóknin gerði ráð fyrir rýniviðtali við barnahópinn nokkrum vikum eftir að smiðjum lauk en vegna aðstæðna í skólanum dróst pað í tíu vikur. Útbúinn var spurningarammi og sneri hann að fjórum páttum. Í fyrsta lagi var spurt um skapandi viðfangsefni í smiðjunum, svo sem um leik, um sögupersónurnar sem börnin hönnuðu, um sögusviðin og sögugerðina en einnig um legokubbana. Í öðru lagi var rætt um stafrænu tækin sem notuð voru, upplifun barnanna og reynslu af peim. Í priðja lagi var spurt um smiðjurnar sjálfar og upplifun barnanna af peim og í fjórða lagi voru spurningar um gagnaöflunina. Spurningarammi var saminn fyrir petta tiltekna viðtal og var hann bæði hefðbundinn en einnig myndrænn par sem settar voru fram ljósmyndir frá smiðjum barnanna sem taldar voru lýsandi fyrir viðfangsefnið sem spurt var um. Tilgangur peirra var að leiða umræðuna og gefa börnunum tæki til að rifja upp pað sem fram fór. Jóhanna Einarsdóttir (2012b) segir pekkta aðferð að taka viðtöl við börn með pað að markmiði að líta til baka en pað er aðferðin sem hér var beitt. Pegar börnum er gefið færi á að líta yfir gögnin eftir á, eins og gert var í rannsókninni, hafa pau möguleika á að draga fram atriði sem voru ekki endilega ljós á meðan á rannsókninni stód. Pau hafa pá færi á að sjá verkefnið í nýju ljósi og petta gefur peim einnig tækifæri til að hugsa um pað sem pau hugsuðu (e. metacognition) pegar verkefnið var í gangi. Rannsakandinn hefur einnig færi á að læra meira um börnin og getur meðal annars rætt við pau um atriði eins og viðveru rannsakandans (Merewether og Fleet, 2014). Chadwick og Webster (2010) benda á að pá geti verið gagnlegt að hafa eitthvað í höndunum sem hjálpar til við 
samtalið og nýttust ljósmyndirnar vel til pess. Rýniviðtalið var tekið upp og síðan afritað áður en pað var pemagreint. Helstu pemun sem fram komu voru smiðjurnar, skapandi verkefni, tækin og að lokum rannsakendurnir.

\section{Sampykki og siðferðileg álitamál}

Degar farið var af stað með heildarrannsóknina var leitað sampykkis Persónuverndar og sveitarfélagsins par sem rannsóknin fór fram. Pá gáfu skólastjórnendur leyfi fyrir bví að rannsóknin færi fram í viðkomandi skóla. Næsta skref var að fá kennara og kennaranema til samstarfs sem báðir skrifuðu undir upplýst sampykki, meðal annars fyrir leyfi til að nota upptökur og ljósmyndir 1 tengslum við kynningar á niðurstöðum. Upplýst sampykki er siðferðilega mikilvægt og lagaleg skylda rannsakenda (Chadwick og Webster, 2010). Áður en rannsóknin fór fram skrifuðu foreldrar undir sampykki fyrir pátttöku barnanna í smiðjunum og hvernig nýta mætti gögn, meðal annars myndir og myndbandsbrot, til að kynna rannsóknina. Í fyrstu smiðjunni settist rannsakandinn niður með börnunum og ræddi við pau um rannsóknina, til hvers væri ætlast af peim, hvers vegna rannsóknin væri gerð, hvað gert yrði við gögnin og peim gert ljóst að pau gætu beðið um að hætta hvenær sem væri og færu pá inn í barnahópinn á deildinni sinni. Petta eru allt atriði sem er mikilvægt að gera pátttakendum í rannsóknum ljós (Mukherji og Albon, 2010).

Langston, Abbott, Lewis og Kellett (2004) segja pekkt að börn geti brugðist við með fernum hætti í rannsóknaraðstæðum, a) pau geta neitað að bregðast við rannsakendum og til að vinna á móti peim áhættupætti bar kennarinn peirra hitann og pungann af leiðbeiningum og útskýringum til barnanna sem og samskiptum við pau og var með peim allan tímann, b) pau geta brugðist við með pví að verða óeðlilega hlédræg, c) pau geta verið ósamvinnupýð, d) pau geta hunsað viðfangsefnið eða sýnt vanlíðan. Allt kallar á að rannsakendur séu vakandi fyrir líðan barnanna og lesi í viðbrögð og líkamstjáningu. Kennari barnanna, kennaraneminn og rannsakendur voru meðvitaðir um ofangreinda pætti og höfðu vakandi auga fyrir líðan barnanna. Í nokkrum tilvikum ræddi kennari eða rannsakandi sérstaklega við einstaka barn og bauð bví í kjölfarið að hætta pátttöku pann daginn. Í engu tilviki valdi barn að yfirgefa smiðju. Upplýst sampykki var rifjað upp með börnunum í upphafi og af og til í gegnum smiðjurnar.

Ein af siðferðisspurningunum sem parf að svara pegar börn eru pátttakendur í rannsókn er hver hagur peirra sé af pátttöku (Mukherji og Albon, 2010). Smiðjurnar gáfu börnunum tækifæri til að læra og leika með nýja tækni og öðlast færni og reynslu sem pau hefðu annars farið á mis við. Einnig var pess gætt að pau börn á deildinni sem ekki tóku pátt í rannsókninni vissu að eftir að smiðjum lauk fengju pau að nota stafrænu tækin í nokkrar vikur. Að lokum má nefna að sérstaklega var gætt að pví að fara eftir lagalegum og siðferðilegum kröfum um örugga geymslu gagna en pau voru vistuð á öruggu vefsvæði og aðgangur að peim takmarkaður (Palaiologou, 2016).

\section{Niðurstöður}

Niðurstöður taka til prenns konar gagna; mats barna í lok hverrar smiðju, dagbóka rannsakenda og rýniviðtals við börnin eftir að smiðjum lauk. Um leið og gerð er grein fyrir niðurstöðum eru fléttaðar inn nauðsynlegar bakgrunnsupplýsingar um pað sem börnin voru að fást við hverju sinni. Fjallað er um notkun barna á tilfinningatáknum, gerð grein fyrir mati peirra á pátttöku í rannsókninni og dagbækur rannsakanda eru fléttaðar inn í niðurstöður.

\section{Notkun barna á tilfinningatáknum}

Langalgengast var að börnin gæfu smiðjunum brostákn en í lokin voru brostáknin orðin 45 af 56 tilfinningatáknum á matsblöðum barnanna. Smiðjurnar fengu sex merkingar við hlutlausa táknið. Par af gaf einn drengjanna prjár peirra en ein stúlkan tvö en sú átti einnig tvö af fimm 
skeifutáknum sem komu fram. Degar rýnt er í mat stúlkunnar kom í ljós að hún var í raun að meta tiltekna pætti í smiðjunni en ekki smiðjuna sem heild. Bæði skeifutáknin voru tilkomin vegna pess að henni gekk illa að stjórna Mæju. Mæja var einnig ástæðan fyrir öðru hlutlausa tákninu og stúlkan útskýrði pað með pví að segja „Mæja keyrði á allt“, en sömu smiðjum gaf hún fleiri en eitt tákn, valdi bæði hlutlaust og brosandi tákn og útskýrði jákvæða táknið með pví að segja аð раð væri gaman að vera fréttamaður í fréttahorninu og svo væri líka gaman að lita. Í annað sinn gaf hún hlutlaust tákn pegar hún hafði haft áhuga á að komast að í fréttahorninu en pað var upptekið. „Mig langaði í viðtal“, sagði hún. Má segja að petta hafi verið nokkuð dæmigert fyrir mat barnanna, pau voru að meta tiltekna pætti og jafnvel út frá atvikum sem áttu sér stað rétt áður en matið fór fram. Úr dagbók frá smiðju 1 segir: „Sem dæmi fannst einni dömu að petta hefði ekki verið skemmtileg stund ... pegar kennari spurði nánar var næstum allt skemmtilegt en sumt eins og hún purfti að bíða eða teikna ekki eins skemmtilegt.“ Баð var pví strax í fyrstu smiðju sem rannsakendur gerðu sér grein fyrir að notkun barna á tilfinningatáknum kom peim á óvart og dró fram pá staðreynd að peir voru með hugmyndir um að börnin myndu nota táknin yfir heildarupplifun fremur en afmarkaða pætti. Í færslu úr sömu dagbók segir einnig:

[Рað var] hins vegar afar gaman að sjá pegar kennarinn var að spyrja um líðan peirra í lok tímans. Sum sem höfðu verið hin glöðustu, fannst petta svo bara leiðinlegt. En svo kom í ljós að pað var kannski eitthvað eitt atriði.

Detta sýnir að petta atriði var ákveðinn lærdómur fyrir rannsakendur og gerði pað að verkum að peir gáfu mati barnanna enn meiri gaum í smiðjunum sem á eftir komu. Á mynd 2 má sjá barn skýra út val sitt með kennara.

Dæmi um val á skeifutáknum var pegar stúlka gaf smiðju skeifutákn og sagði pað vera vegna pess að hún hafði „skemmt flugvél“ '́ smiðjunni og pað pótti henni leiðinlegt. Stundum völdu börnin að merkja við fleiri en einn möguleika. Í einni smiðju gaf stúlka tvö tákn og útskýrði af hverju hún valdi tvo möguleika svona: „Broskarla af pví að pað er gaman í Mæju og að teikna en [skeifutákn] af pví að mig langaði að prófa myndavélina. Dað var erfitt að stýra Mæju“. Í pessu tilviki var skeifutáknið notað til að lýsa pví að viðfangsefni í smiðjunni var barninu áskorun.

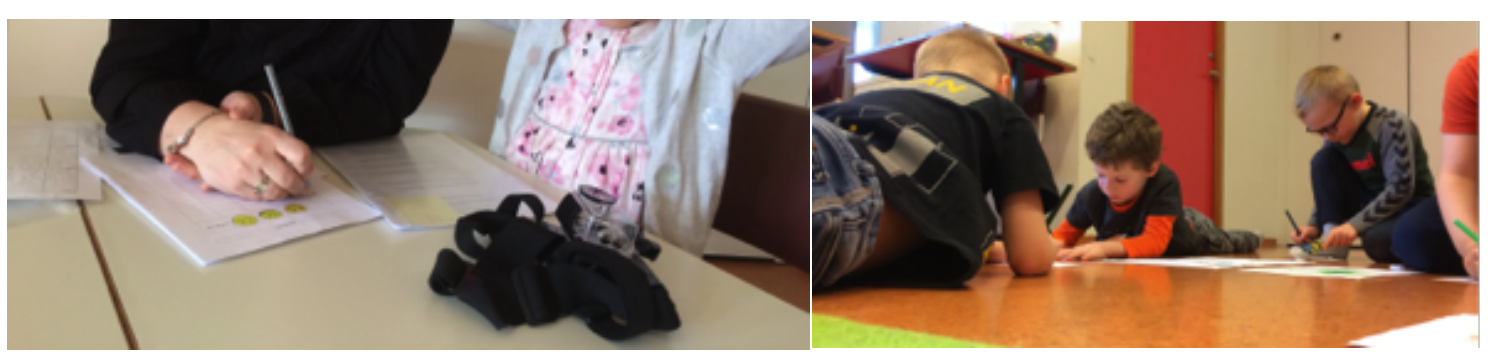

Mynd 2. Barn útskýrir val sitt fyrir kennaranum Mynd 3. Börnin hanna persónur sínar

Drengur útskýrði notkun á tveimur táknum með orðum og bendingum: „Fyrst J svo L, ekki gaman fyrst en svo varð gaman“. Í smiðju fjögur voru börnin farin að nota fleiri orð til að útskýra mat sitt. Sterkustu lýsingarorðin komu fram í smiðju sex en pað var smiðjan par sem börnin fengu að ráđa sjálf og engar leiðbeiningar voru gefnar. „Geggjað gaman ... allt“. Virkari pátttaka barnanna í umræðu um mat sitt og skýrari lýsingar gefa vísbendingu um ákveðna próun eftir pví sem börnin vöndust aðferðinni. 
Tafla 1. Mat á barna á smiðjum í viðtölum

\begin{tabular}{ccccccc}
\hline $\begin{array}{c}\text { Viðfangs- } \\
\text { efni }\end{array}$ & Mæja & $\begin{array}{c}\text { Stafrænir } \\
\text { kubbar }\end{array}$ & $\begin{array}{c}\text { Frétta- } \\
\text { hornið }\end{array}$ & $\begin{array}{c}\text { Hannað og } \\
\text { teiknað }\end{array}$ & $\begin{array}{c}\text { Lego- } \\
\text { kubbar }\end{array}$ & Allt $^{\star}$ \\
\hline Smiðja 1 & 6 & ekki í boði & 2 & 3 & - & 1 \\
Smiðja 2 & 5 & ekki í boði & 2 & - & 1 & 3 \\
Smiðja 3 & 5 & 5 & - & - & 2 & 3 \\
Smiðja 4 & 3 & 4 & - & 2 & - & 2 \\
Smiðja 5 & 2 & 1 & - & - & 2 & 1 \\
Smiðja 6 & - & 4 & - & - & 1 & - \\
Samtals & 21 & 14 & 4 & 5 & 6 & 10 \\
\hline
\end{tabular}

^Hér eru pau svör barnanna pegar pau sögðu að allt væri gaman, mjög gaman eða jákvætt.

Degar börnin mátu smiðjurnar nefndu pau oftast að peim pótti gaman að leika með Mæju en stafrænu kubbarnir voru einnig vinsælir en minna má á að peir voru ekki í boði í fyrstu tveimur smiðjunum og parf að hafa pað í huga pegar lesið er úr niðurstöðum. Eins og sjá má í töflu 1 fengu legokubbarnir, hönnunarvinnan og fréttahornið sambærilegan fjölda jákvæðra umsagna en 1 orðuðu mati nefndu börnin smávélina aldrei. Tíu sinnum nefndu börnin varðandi öll viðfangsefnin orðin skemmtilegt, gaman eða mjög gaman og fréttahornið var nefnt sérstaklega sem ánægjuefni fjórum sinnum.

Ábendingar barnanna um pað sem var gaman eða áhugavert náði til flestra viðfangsefna en pau nefndu einnig pað sem peim pótti síðra eða leiðinlegt: ,... gaman að vera fréttamaður og með Mæju ... bara held ég ... leiðinlegt að teikna“. Á mynd 3 má sjá börnin teikna persónurnar sínar og í matinu var teikning nefnd fimm sinnum sem ánægjuleg upplifun. Í einu tilviki nefndi barn að pví pætti leiðinlegt að hafa ekki komist að í viðfangsefni sem pað langaði að taka pátt í.

\section{Reynsla barna af smiðjum}

Eitt af fyrstu verkefnum barnanna í smiðjum var að teikna sögupersónur. Degar pau rifjuðu upp fyrstu smiðjuna í rýniviðtali nefndu pau Mæju jarðarber, fiðrildi og einn drengurinn rifjaðu upp að hann teiknaði sjálfan sig sem ofurhetju. Aðspurð um tilgang sögupersónanna sagði eitt barnið: „Til pess að hún [Mæja] gæti heimsótt einhvern“.

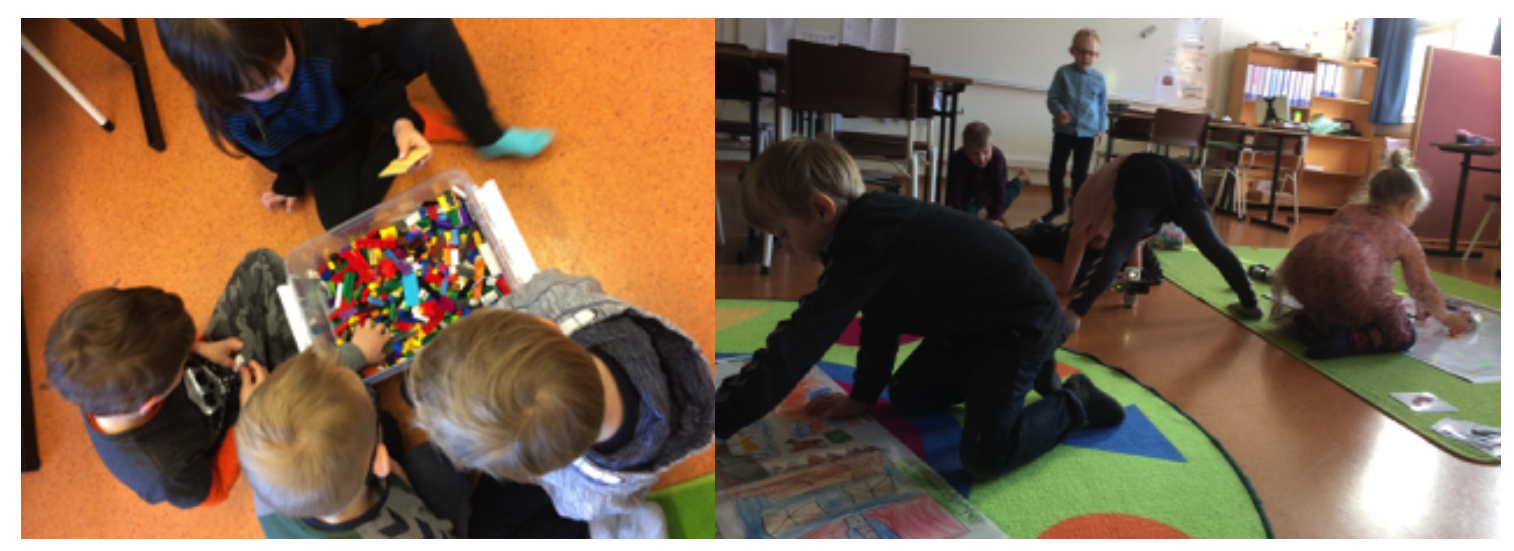

Mynd 4. Byggt úr legokubbum fyrir sögusvið Mynd 5. Börnin vinna í smiðju 
Rætt var um hvað var áhugaverðast í smiðjum og fyrstu viðbrögð nokkurra barna var að svara með pví að segja að allt hefði vakið áhuga. Síðan fóru pau að nefna dæmi svo sem: „Degar við vorum að búa til sögusviðið“, „,pegar við vorum að lita persónurnar okkar“, „,pegar við vorum аð lita húsin“, „... gera kastalann“ og að lokum „,að vera með Mæju og kubbana ... búa til““. Eins og sjá má mátu börnin verkefni sem voru skapandi og pau höfðu stjórn á sem áhugaverð og skemmtileg. Sambærileg niðurstaða kom fram pegar börnin ræddu pað sem pau höfðu gert síðan smiðjunum lauk og voru pá að ræða Mæju. Deim varð tíðræett um pað sem pau sköpuðu fyrir Mæju; ,,[аð] byggja og kubba fyrir hana“ og ,,byggja líka“. Samræða barnanna um skapandi viðfangsefnin er einnig sá páttur í smiðjunum sem pau virtust hafa mest um að segja eins og sjá má á eftirfarandi bút úr viðtalinu og átti sér stað pegar pau ræddu pað sem pau gerðu með legokubbunum fyrir Mæju:

Barn 1: Skóginn.

Barn 2: Fjöll og brú svo Mæja geti farið undir pað.

Barn 3 ... og göng.

Barn 4: ... og hús.

Barn 3: ... og örvarnar.

Rannsakandi: Бið notuðuð örvarnar mikið.

Barn 3: Já, smá.

Barn 2: Ég notaði pað ekkert.

Barn 5: ... og fiskabúr.

Legokubbarnir voru vinsælir og börnin notuðu pá á margvíslegan máta, meðal annars til að gera hindranir fyrir Mæju og byggja persónurnar sínar (sjá mynd 4). Ein stúlkan byggði myndavél sem hún staðsetti inni í sögusviðinu til að taka ferðir Mæju upp og var par með ef til vill að endurspegla rannsóknarumhverfið sem hún var í. Í dagbók frá smiðju 2 lýsir rannsakandi sama atviki:

Ein stúlkan byggði myndavél úr legokubbum og staðsetti við enda brautarinnar til að taka upp pegar Mæja kæmi. Myndavélina staðsetti hún pannig að hún tók mynd framan á Mæju ferðast í áttina að markinu. Ekki veit ég hvort hún var að endurgera mín verk en ég hafði verið að mynda í kringum pau eða hvort hún var að endurgera ípróttaleik með öllum peim myndatökum sem par eiga sér stað, t.d. við marklínuna.

Á mynd 5 má sjá dæmi um viðfangsefni barna í smiðjum, sum eru að leika með Mæju fremst hægra og vinstra megin á myndinni en aftar fyrir miðju er hópur barna að láta stafrænu kubbana ferðast um rýmið.

Börnin voru ekki alltaf sammála pegar pau ræddu um smiðjurnar. Dau rifjuðu upp pætti í peim sem voru áhugaverðir og snerust í öllum tilvikum um verkefnin sem pau unnu sjálf, svo sem: „Ég gerði kastalann“. Dó börnunum væri tíðrætt um að smiðjur væru skemmtilegar pá nefndu tvö barnanna á pessum stað í viðtalinu að peim hefði pótt leiðinlegt að mæta svona oft og í kjölfarið ræddu börnin um hve margar smiðjur hefðu átt að vera að peirra mati. Einn drengjanna útskýrði heppilegt umfang með orðunum „,svona fjórum sinnum“. Hin börnin voru ekki sammála og sögðu ákveðið nei og eitt barnanna lagði fram pá skoðun að tíu sinnum hefði verið ágætur fjöldi en pví svaraði annað barn fljótt: „Nei, ekki tíu sinnum, pá verðum við, held ég, mjög preytt“. Börnin töldu pví fjórar til sex smiðjur hentugan fjölda en vildu ekki endilega að pær væru fleiri.

\section{Viðfangsefnin}

Viðfangsefni barnanna í smiðjum voru vélveran Mæja (e. Blue-bot) og stafrænir kubbar (e. Cubelets) og börnin notuðu hvoru tveggja með sögupersónum og sögusviðum sem pau hönnuðu en einnig með legokubbum. Börnin voru sammála um að Mæja virkaði vel og eitt barnið lýsti 
pví hvernig Mæja virkar á pessa leið: „Ýta á takkana og kveikja og slökkva“, en annað barn sagði, og setti pað fram sem leiðbeiningu til annarra barna sem ekki pekktu Mæju: „... ýta alltaf á X áður en pau byrja og ýta á eitthvað annað“. Deim fannst auðvelt að skilja hvernig Mæja virkar en rifjuðu einnig upp sögur af pví pegar hún gerði ekki alveg pað sem pau vildu að hún gerði: „Mæja var samt að bakka, pegar ég var að reyna að fara áfram“. Annað barn talaði um svipað atvik og pótti pað gaman: „Mér fannst gaman pegar hún var að fara út af mottunni“.

Hópurinn ræddi fyrirstöðurnar sem pau byggðu úr legokubbum fyrir Mæju: „Við purftum að gera eitthvað svona svo að Mæja kæmist í gegn“, dæmi um petta má sjá á hliði sem barn byggði og sjá má á mynd 6 en pau ræddu einnig sögurnar sem Mæja tók pátt 1́: „,.. og við gerðum skóg og úlfa“. Eitt barnanna tók upp práđinn og sagði: „Ég byrjaði að gera úlfa“. Börnunum póttu tengsl Mæju og ævintýranna mikilvæg og lýstu peim sem skemmtilegum: „Að sko ... ummm ... að láta hana fara fram hjá skóginum, pví að úlfarnir máttu ekki koma“, og annað barn hélt umræðunni áfram: „,.. pegar hún var að reyna að fara út úr skóginum“.
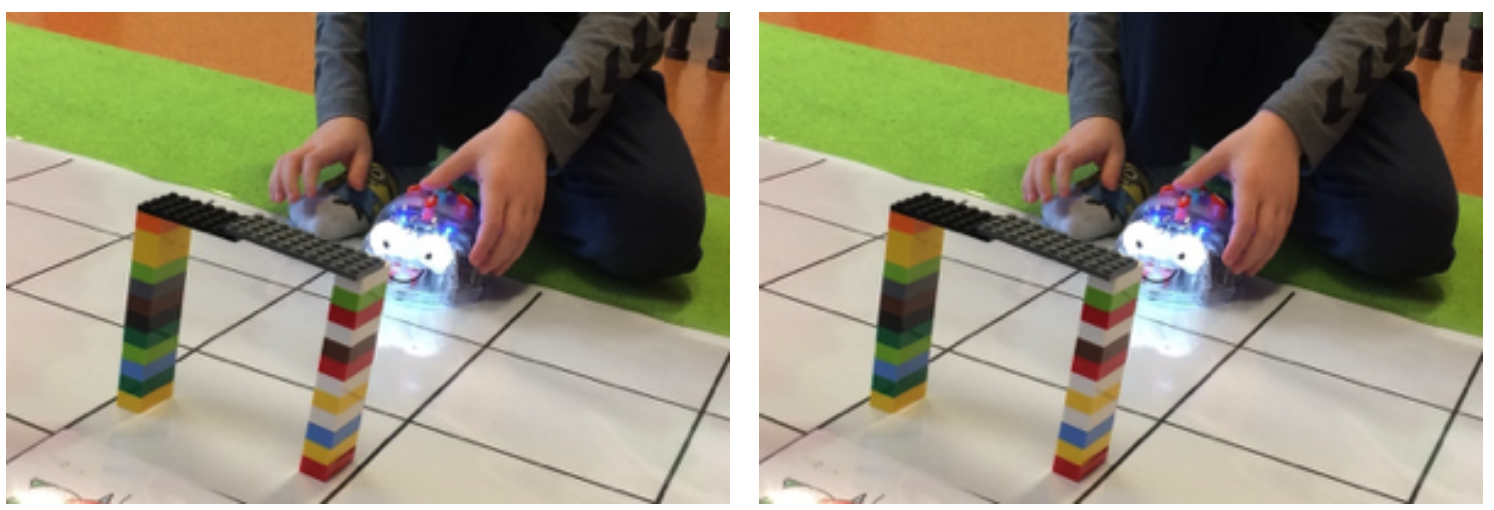

Mynd 6. Hlið fyrir Mæju að ferðast í gegnum Mynd 7. Samvinna með Mæju

Önnur börn nefndu legokubbana sem áhugavert viðfangsefni, sérstaklega pegar pau notuðu kubbana til að byggja sögupersónurnar sem pau teiknuðu: „,.. að byggja persónuna mína úr legokubbunum“ og annað barn sagði: „Já, við notuðum meira lego og líka örvarnar og við teiknuðum líka á blað eitthvað svona til að láta hana fara inn í.“ Á mynd 7 má sjá börnin vinna saman að pví að forrita Mæju til að fara tiltekna leið.

Börnin ræddu um muninn á milli Mæju og stafrænu kubbanna og pó pau væru sammála um að bæði leikföngin vektu áhuga peirra bentu sumir drengjanna á myndir af kubbunum á meðan samræðan fór fram. Deir lýstu virkni kubbanna svona: "Já gaman. Við settum svona nokkra kubba saman, við bara festum pá á, pað var líka svona snúningskubbur. Já og rafmagns“. Stúlka talaði um kubbana og hvernig persónan hennar hreyfðist mikið og hratt pegar hún var komin á kubb:. „Hún fór alveg svakalega hratt, ég náði ekki að stoppa hana“. Börnin nefndu sérstaklega að straumkubburinn og hjólakubburinn væru uppáhaldskubbarnir enda peir kubbar sem hafa hvað mesta virkni en ein stúlkan sagði: ,... en mér fannst svolítið erfitt að kveikja á rafmagnskubbnum“. Einn drengjanna tók sem dæmi að pað væri samvinnan sem honum pótti skemmtilegust við verkefnið: „Skemmtilegast pegar við vorum saman að byggja úr peim“.

\section{Upptökuvélar}

Eitt af pví sem var hluti af gagnaöflun var að börnunum var boðið upp á að nota smámyndavél (GoPro) í bringufestingu. Vélina máttu pau setja á sig pegar pau vildu eða skiptast á pegar áhugi á að hafa vélina var meiri. Fljótlega mátti sjá börnin reyna að sjá á skjá vélarinnar og rannsakendur losuðu um vélina svo börnin gætu tekið markvissari myndir enda virtust pau sækjast eftir pví. Á mynd 8 má sjá barn skoða leik annarra barna með smámyndavélinni. Degar pau voru spurð um litlu vélina sagði eitt barnið strax: „Já myndavélina, mér fannst hún skemmtileg, hún var skemmtilegust.“ Einn drengjanna kvartaði yfir pví að stúlka hefði verið mikið með vélina en 
börnin ræddu að allir hefðu fengið að prófa hana ef peir vildu. Börnin sögðu vélina virka vel, útskýrðu pó ekki nánar hvað pau áttu við en hins vegar útskýrðu pau hvað pau gerðu með vélinni: „Taka mynd og leika okkur með hana ... sjá alla“, og útskýrðu að peim líkaði best að horfa í gegnum hana á hin börnin vinna eða á verkefni barnanna: „Á ég að segja pér? Við [nafn á dreng] ... með myndavélarnar ... ég reyndi alltaf að reyna að finna hann með henni“. Í dagbókarfærslu fyrir smiðju 2 skrifar rannsakandi:

Börnin vildu sjá á skjáinn, pau voru sem sé með vélarnar til að taka upp, markvisst sjálf, sem sé stjórna vélinni en ekki bara hafa hana og vinna verkefni. Vélin er pví svo sannarlega frá sjónarhóli barna en einnig notuðu pau hana nær algjörlega til að taka upp önnur börn að leik.

Börnin voru frá upphafi viljug að hafa smávélina og í smiðju 2 segir í dagbók: „Fljótt bað ein stúlkan um að hafa smávélina ... síðan var biðröð eftir að hafa hana og við takmörkuðum pví tímann svo fleiri kæmust að, held að fjögur til fimm börn hafi skipt vélinni á milli sín í dag“. Í smiðju 3 skiptust börnin á að nota smávélina en í smiðju 4 var ein stúlka með vélina nánast allan tímann.

Degar á rannsóknartímann leið urðu börnin uppteknari af rannsóknartækjunum, svo sem upptökuvélinni og í dagbókarfærslu frá smiðju 5 segir:

Undir lok tímans gekk barn að Canon-vélinni, fylgdist með upptökunni og færði svo vélina til og frá til að geta horft á hvað hin börnin voru að gera, að lokum færði pað vélina upp í loft og pótti pað mjög fyndið. Annað barn gerði svipað stuttu síðar og petta mun koma fram á upptökunum.

Sama gerðist í síðustu smiðjunni:

Aftur urðu börnin á tilteknum tímapunkti upptekin af að fylgjast með upptökunum, bæði i Canon-vélinni og ipadinum, göntuðust fyrir framan hana eða horfðu á upptökuna af hinum börnunum. Petta mun koma fram á upptökunum.

Eins og sjá má urðu upptökutækin viðfangsefni leiks pegar á leið á rannsóknina og var pað látið afskiptalaust.

Degar börnin ræddu áhugaverða pætti í smiðjunum nefndu tvær stelpnanna fréttahornið. Önnur sagði: „Taka viðtal og sjá í gegnum [spjaldtölvuna]. Við sögðum hvað við vorum að gera og teikna“. Mynd 9 er tekin í fréttahorninu og sýnir börn taka viðtöl hvert við annað en fréttahornið var einkar vinsælt í smiðjunum framan af.
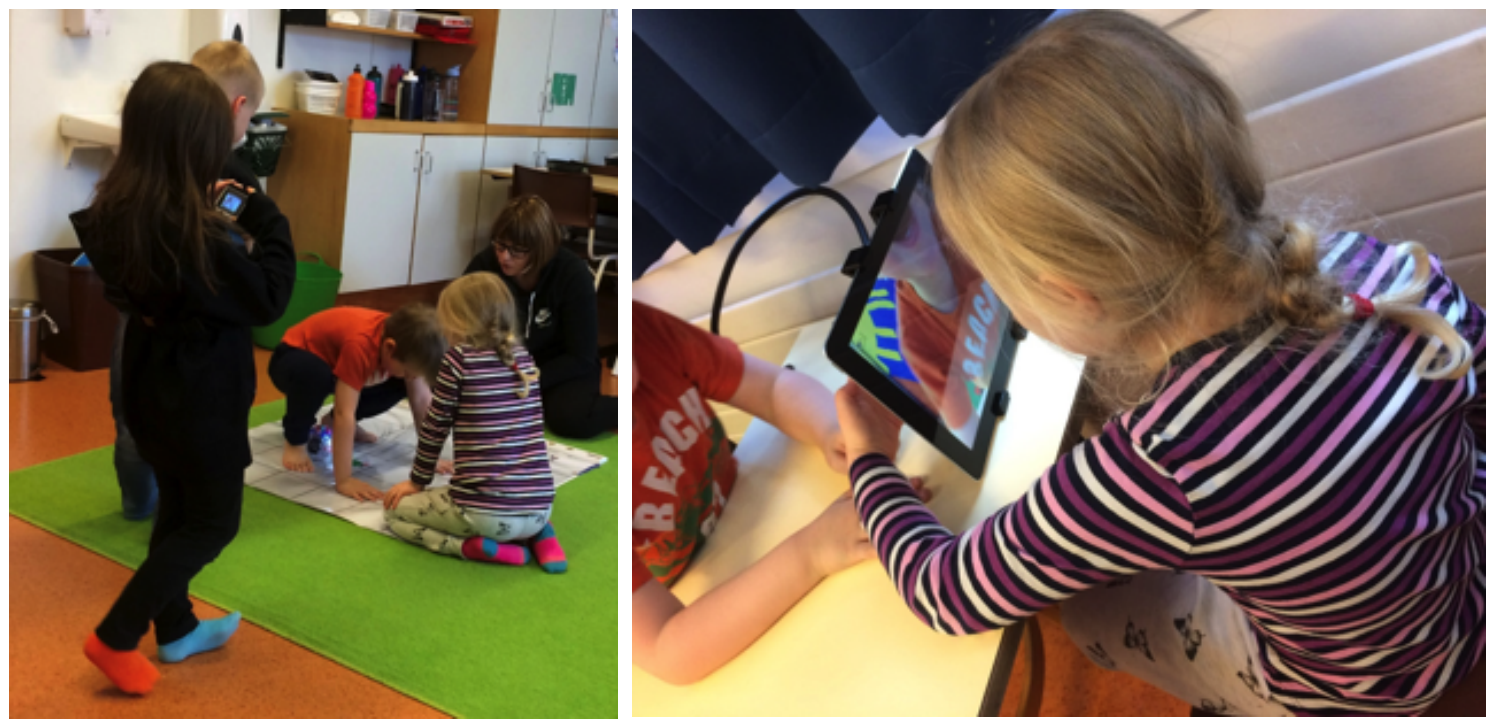

Mynd 8. Að rannsaka með smámyndavél Mynd 9. Viðtal í fréttahorni 
Í rýniviðtalinu kom fram að börnin hefðu viljað að rannsakendur hefðu tekið viðtöl við pau eftir hverja smiðju. Eitt barnið sagði: „Баð hefði mátt spyrja hvað okkur hafi pótt skemmtilegt“. Börnin vildu meiri samræðu sem er áhugavert í ljósi pess að rannsakendum pótti peim pætti pegar vel sinnt. Hugsanlega vildu börnin koma skoðunum sínum og reynslu enn frekar á framfæri beint til rannsakenda en einnig gæeti verið að pau hafi haft meira að segja, eitthvað sem aðferðin náði ekki nægilega vel til.

\section{Rannsakendurnir}

Í smiðjum var einn rannsakandi viðstaddur hverju sinni, börnin ræddu um fjölda fullorðinna í smiðjum og sum lýstu peirri skoðun að viðvera fullorðinna í rýminu gæti truflað, jafnvel pegar peir væru ekki beinlínis að skipta sér af börnunum. Eitt barnið sagði: „Đetta var alveg nóg“. Sum sögðust feimin við petta ókunna fólk en einnig að pað hefði veitt aðstoð pó pær lýsingar væru hikandi: „Já. Já, smá. Já, bara smá“. Börnin vildu pó alveg fá meiri leiðbeiningar en einnig meiri tíma til að leika sér í friði eða eins og eitt barnið svaraði spurningunni um hvað pað vildi helst fá að gera: „Leika okkur meira og meiri kennslu“. Hér gæti verið að tilraunir rannsakenda til að halda sig til hlés hafi virkað á börnin sem áhugaleysi en í dagbók frá smiðju 5 skrifar rannsakandinn færslu um hlutverk sitt í smiðjunum:

Sum [börnin] vildu sýna mér pað sem pau voru að gera, komu til mín með verkin sín eða bara til að spjalla smá stund. Pannig er maður ekki alveg ósýnilegur, hvað sem maður reynir og ég ræddi við pau pegar pau sóttust eftir pví að fyrra bragði.

Í síðustu smiðjunni segir einnig í dagbókarfærslu:

Í dag fannst mér skilin á milli rannsakanda og pátttakanda hverfa að einhverju leyti, börnin leituðu til mín, sýndu mér verkin sín og báđu mig um aðstoð. Kannski vegna pess að [kennaraneminn] var ekki viðstödd í dag, kannski vegna pess að pau pekkja mig núorðið.

Flest barnanna tjáðu sig lítið um aðalupptökuvélina en hins vegar nefndu börnin að ljósmyndataka fullorðinna gæeti truflað leik og einbeitingu: „Баð truflaði líka pegar pær voru að taka mynd pegar ég var að byggja“. Viðvera rannsakanda og athafnir hans höfðu greinilega áhrif á börnin.

Degar litið er til baka er ljóst að börn eru verðugir pátttakendur í rannsókn. Dau nýttu matsblöđin á sinn hátt og voru fullfær um að ræða pátttöku sína í smiðjum tíu vikum eftir að henni lauk.

\section{Umræða og lokaorð}

Markmiðið var að kanna viðhorf og upplifun barna af pátttöku í tilviksrannsókn um sköpunarsmiðjur. Í greiningu gagna var lagt upp með hvernig börnin upplifðu smiðjurnar, eigin pátttöku og rannsakendur. Fjórir meginpættir standa upp úr. Dað er færni barna til pátttöku í rannsókn, mat peirra á smiðjum, vald yfir viðfangsefnum og upplifun af rannsakendum.

Færni barna til pátttöku kom skýrt fram í niðurstöðum. Rýniviðtalið fór fram tveimur og hálfum mánuði eftir að smiðjum lauk og kom í ljós hvað mikið börnin mundu og gátu rifjað upp eftir petta langan tíma. Rannsakendur voru hugsi um hvort of langur tími hefði liðið frá smiðjum og hvort pað hefði í för með sér að börnin hefðu gleymt pví sem fram fór eða misst áhuga á verkefninu. Eftir samræður var ákveðið að treysta á getu barnanna og taka rýniviðtalið. Í ljós kom að minni peirra var gott og færni til að ræða pað sem fram fór var mikil. Dað er í samræmi við hugmyndir Dahlberg, Moss og Pence (2006) sem hafa minnt á mikilvægi pess að hafa trú á pví sem börnin geta og hafa fram að færa og reynslan sýndi að pað var hárrétt mat. Börnin höfðu skoðanir á og rökræddu atvik sem peim póttu jákvæð eða neikvæð, tóku afstöðu til tiltekinna pátta og rökræddu sín á milli pegar skoðanir í hópnum voru skiptar. Börnin voru vel fær um að taka pátt og leggja sitt af mörkum í rýniviðtalinu, gáfu mikilvæga innsýn í rannsóknina og 
veittu pekkingu sem rannsakendur hefðu annars verið án. Dæmi um pað var pegar pau ræddu fjölda smiðja en pau voru ekki sammála um hve margar pær hefðu átt að vera, einn vildi færri og annar fleiri en sú tillaga var afgreidd með útskýringu hve preytt pau yrðu pá. Börnin færðu rök og voru ekki alltaf sammála. Bradwell o.fl. (2011) segja petta einn helsta kost pátttökurannsókna, pað er að ná fram sýn barnanna sjálfra, pví pannig fáist vitneskja og skilningur sem erfitt getur verið að ná fram með öðrum hætti. Reynslan af rýniviðtalinu styður einnig við niðurstöður rannsókna sem sýna að börn hafa færni og getu til að taka pátt í umræðum um málefni sem skipta pau máli og pau hafa áhuga á (Alaca o.fl., 2016). Spurningaramminn í rýniviðtalinu var studdur með ljósmyndum og rannsakendur eru sannfærðir um að myndirnar auðvelduðu börnunum að muna og rifja upp. Рað hefur sýnt sig að ljósmyndir geta nýst sem hjálpartæki í viðtölum við börn (Jóhanna Einarsdóttir, 2008).

Mat á smiðjum er meðal pess sem rannsakendur veltu fyrir sér. Eins og fram kom í niðurstöðukafla mátu börnin smiðjur með tilfinningatáknum. Ein ástæða pess að valið var að nota táknin er að pau eru vel pekkt í umhverfi barna, rannsakendur töldu að börnin pekktu pau og hefðu jafnvel persónulega reynslu af peim. Pegar á hólminn var komið notuðu börnin táknin ekki á einn máta heldur margvíslegan, táknin gátu staðið fyrir upplifun af smiðju í heild sinni en oftar stóð hún fyrir upplifun af einstaka páttum. Stundum kallaði pað á að sama smiðja væri metin með margvíslegum táknum sem pá urðu eins og tímalína sem lýsti upplifun viðkomandi barns. Lærdómurinn sem rannsakendur draga af pessum pætti er pví tvenns konar, annars vegar að börn geta notað táknin með öðrum hætti en fullorðnir. Hins vegar parf að gæta vel að notkun tilfinningatákna við mat og fylgja peim eftir með einhverjum peim hætti sem skilur ekki eftir ráðrúm til oftúlkunar. Nilsson o.fl. (2013) telja að túlkun geti gefið skakka mynd ef hún er ekki sannreynd með einhverjum hætti. Má í pví ljósi velta fyrir sér hversu mikilvægt var að börnin fengu bæði tækifæri til að setja eigin orð og útskýringar á táknin og að peim gafst tækifæri til að ræða smiðjurnar í rýniviðtali. Eftir á að hyggja var mikilvægt að fá útskýringu barnanna á hvers vegna pau merktu við tiltekin tilfinningatákn pví pá gáfu pau skýringar sem ekki lágu endilega í augum uppi. Hér má minna á að börnin kölluðu eftir að rannsakendur tækju viðtal við pau í lok hverrar smiðju sem er í samræmi við niðurstöður Lundy og McEvoy (2012) um að tækifæri til pátttöku geti verið gefandi fyrir börnin og að pátttaka geti eflt sjálfstraust barnanna.

Verkefni sem börnin höfðu vald yfir vöktu hjá peim mesta ánægju, bæði verkefni sem snerust um sköpun og tækjabúnað. Viðfangsefnin sem pau stýrðu sjálf heilluðu pau mest, má par nefna smámyndavélina, stafrænu tækin, legokubba, liti og blöð sem pau notuðu til að skapa persónur og sögusvið og pað að taka viðtöl hvert við annað með spjaldtölvu. Börnin sóttust eftir að hafa smámyndavélina á sér en um leið reyndu pau að ná sem mestri stjórn á henni, með pví að beina henni að öðrum börnum og verkum peirra. Pau upplifðu vélina sem leik og fannst gaman að horfa á hin börnin vinna. Sama gilti um fréttahornið, par upplifðu pau bæði frelsi og vald. Gera má ráð fyrir að upptökumöguleikarnir hafi gefið börnunum sambærilegt vald og ljósmyndun barna í rannsóknum Änggård (2015). Dær voru vísbending um hvað vakti áhuga barnanna um leið og pær gáfu peim færi á að stjórna gagnaöfluninni á eigin forsendum. Í pví samhengi verða börnin rannsakendur og geta rýnt í pað sem peim pykir mikilvægt eins og fram kom hjá Cook og Hess (2007).

Upplifun barnanna af rannsakendum vakti athygli. Einn af peim páttum sem kom skýrt fram í niðurstöðum er að sum barnanna upplifðu viðveru rannsakenda í smiðjum sem truflandi. Sama hefur komið fram í fleiri rannsóknum (s.s. Hrönn Pálmadóttir og Jóhanna Einarsdóttir, 2015). Rannsakendur sem vinna rannsóknir með börnum purfa að hafa petta atriði í huga pegar rannsóknarsniðið er formað. Til að vinna gegn pví er mikilvægt að takmarka fjölda fullorðinna í rýminu og pá sérstaklega fullorðinna sem börnin pekkja ekki. Chadwick og Webster (2010) hafa bent á að prátt fyrir góđan ásetning sé auðvelt í hita leiksins að gleyma sér og fara yfir mörk barnanna. Раð kom líka fram að börnunum fannst stundum upptökuvélar hinna fullorðnu geta truflað einbeitingu peirra við verkefnin. Allt eru petta mikilvæg atriði sem rannsakendur purfa að hafa í huga pegar rannsóknir eru unnar með börnum. Guðrún Kristinsdóttir og Hervör Alma Árnadóttir (2015) bentu á mikilvægi pess að rannsakendur hefðu bæði hæfni til pess að ræða við 
börn og pekkingu á börnum og aðstæðum peirra. Рað má pví velta fyrir sér hvort í rannsóknum með börnum sé æskilegt að pau fái tækifæri til að kynnast rannsakendum að einhverju marki áður en að gagnaöflun kemur.

Dessi rannsókn er framlag til umræðu um börn sem virka pátttakendur í rannsóknum og rennir stoðum undir að pau geti lagt sitt af mörkum í umræðu um leikskólastarf og á öðrum sviðum samfélagsins. Niðurstöður gefa tilefni til að ýta undir og auka pátttöku barna í ákvörðunum sem pau varða, eins og peim ber réttur til samkvæmt Barnasáttmálanum.

\section{Preschool children's assessment of participating in a case study}

This article explores children's assessment of participating in research on makerspaces in preschool in Iceland. The study is based on data gathered during the spring and summer of 2018. Nine five-year-old children participated in temporary makerspace set up in their preschool. Six workshops were conducted where the children were given opportunities to play with digital toys, Lego and other creative materials. During the workshop, researchers gathered data through different methods, such as using a video camera on tripod and a camera controlled by the researchers, as well as a GoPro camera and iPad which the children controlled. Field notes and research diaries were written and interviews conducted. The children's teacher led the makerspace workshops. The members of the children's group, four girls and five boys, were elected by the teacher. The group was supposed to reflect the diversity of both the whole class and their preschool, in gender, social status and learning dispositions. Informed consent was gathered form all concerned, children included. After each workshop the children filled out an evaluation form, first alone and then with their teacher who wrote down comments. The evaluation form contained three emoji; smiling, neutral and downcast faces as well as a space to give comments. Ten weeks after the workshops were concluded a focus group interview with all the children was conducted with support materials, such as photos to revisit the children's time in the makerspace. In between the workshops and the focus group interview the whole class had access to the digital toys. The study was based on the view that children are powerful and enabled persons with their own voices who can and do have something to say about their learning, participation and experiences. In this article the data from the focus group and the evaluation forms from the children were analysed and the field notes used to give a fuller account of the data.

The main findings indicate that children are both able and have something to say about their experiences during the workshops and research. When looking at the data from the evaluation forms, it is clear that most marked the smiling (45 out of 56 emoji), five the neutral and six the downcast emoji. The children considered activities they had most control over as most important and fun; those included a Blue Bot, GoPro camera and an iPad which they used to interview each other. They liked to use the GoPro camera as part of their play and to observe one another. In the beginning, the GoPro was positioned at their chest, but when the researchers noticed that they wanted to be able to have a look at the screen, the GoPro was loosened to give the children opportunities to use it as they wanted. How the children used the emoji was of great interest to the researchers and triggered questions about how children understand and use emoji. The emoji did not stand alone as an evaluation; the children's comments and explanations made the researchers aware that they used the emoji to explain parts of the workshops, not the overall feelings. For example if they had problems with coding or getting to use the GoPro or iPad, they chose a downcast emoji even if they were satisfied with the remainder of the workshop. The focus group interview took place ten weeks after the workshops finished and the 
researchers were a little worried that too much time had passed and the children might not be interested in talking about their experiences. They even wondered whether the children had forgotten their experiences. This was not the case, the children were both interested and had a lot of opinions about the project. They discussed, reflected and made critical comments about their experiences. The children made comments about the researchers and their role in the workshops. They thought the adults could be disturbing, especially when the cameras were in their face, so to speak. They also made remarks about the number of grown-ups in the room and did not want more people.

What stands out as learning is that children are able participants in research, but at the same time the researchers have to be careful in their roles and not overstep the children's boundaries.

Key words: Participatory research, young children, the voices of children.

Rannsóknin var styrkt af rannsóknarsjóði Háskólans á Akureyri.

\section{Um höfundana}

Anna Elísa Hreiðarsdóttir (annaelisa@unak.is) er lektor við kennaradeild Háskólans á Akureyri. Hún brautskráđist frá Fósturskóla Íslands árið 1990 sem fóstra, lauk B.Ed.gráđu frá Háskólanum á Akureyri árið 2000 og M.Ed.-prófi sex árum síðar frá sama skóla. Anna Elísa starfaði um árabil sem leikskólastjóri, aðstoðarleikskólastjóri og deildarstjóri í leikskóla. Rannsóknir hennar og próunarverkefni snúa meðal annars að foreldrasamstarfi, jafnrétti, starfi með elstu börnum leikskólans og tölvum og tækni í leikskólastarfi par sem skapandi starf og leikur er í fyrirrúmi.

Kristín Dýrfjörð (dyr@unak.is) er dósent við kennaradeild Háskólans á Akureyri. Kristín starfaði sem leikskólastjóri í um áratug og var virk í félagsstörfum fyrir Félag leikskólakennara. Hún tók pátt í að rita síðustu tvær ađalnámskrár leikskóla. Rannsóknir hennar snúa að lýðræði í starfi leikskóla, skapandi starfi í leikskólum og áhrifum stefnumótunar og hugmyndafræði á leikskólastarf.

\section{About the authors}

Anna Elísa Hreiðarsdóttir (annaelisa@unak.is) is an assistant professor at the Faculty of Education, University of Akureyri, Iceland. She graduated as a kindergarten teacher in 1990, holds a B.Ed. degree in preschool teaching (2000) and has a teacher certificate in pre- and compulsory schools. She completed an M.Ed. with emphasis on school leadership and management from the University of Akureyri (2006). Anna Elísa has experience as a preschool teacher and principal. Her research focuses on preschool and young children; play, creativity and computers and technology but also gender in preschool settings.

Kristín Dýrfjörð (dyr@unak.is) is an associate professor at the University of Akureyri, School of Humanities and Social Sciences, Faculty of Education. She has long-term experience as a preschool principal in Reykjavík, has worked for the teachers' union and taken part in the development of the national curriculum at the Ministry of Education, both before and after taking up a position as a scholar in academia. Her research interests are: early childhood studies, democracy, policy studies and the connection between science and creativity in early childhood. 


\section{Heimildir}

Alaca, B., Rocca, C. og Maggi, S. (2016). Understanding communities through the eyes and voices of children. Early Child Development and Care, 187(7), 1095-1113. doi:10.1080/03004430.2016.1155567

Albon, D. og Barley, R. (2018). Ethnographic research: A significant context for engaging young children in dialogues about adults' writing. Journal of Early Childhood Literacy, O(0), 1-22. doi:10.1177/1468798418805132

Anna Magnea Hreinsdóttir. (2012). Hver hlustar? Í Jóhanna Einarsdóttir og Bryndís Garðarsdóttir (ritstjórar), Raddir barna (bls. 75-98). Reykjavík: Rannung og Háskólaútgáfan.

Aubrey, C., Blackburn, C., Jones, C. og Lowe, R. (2017). The regulated child. Í A. Owen (ritstjóri), Childhood today (bls. 61-73). London: Sage.

Bolzan, N. P. og Gale, F. (2011). Expect the unexpected. Child Indicators Research, 4(2), 269-281. Sótt af https:// link.springer.com/article/10.1007/s12187-010-9098-7

Bradwell, J., Crawford, D., Crawford, J., Dent, L., Finlinson, K., Gibson, R., .. Kellett, M. (2011). How looked after children are involved in their review process. Child Indicators Research, 4(2), 221-229. Sótt af https:// link.springer.com/article/10.1007/s12187-010-9104-0

Chadwick, D. og Webster, A. (2010). Listening to young children and each other. Í J. Glazzard, D. Chadwick, A. Webster og J. Percival (ritstjórar), Assessment for learning in the early years foundation stage (bls. 78-100). London: Sage.

Clark, A. (2011). Breaking methodological boundaries? Exploring visual, participatory methods with adults and young children. European Early Childhood Education Research Journal, 19(3), 321-330. doi:10.1080/1 350293X.2011.597964

Cook, T. og Hess, E. (2007). What the camera sees and from whose perspective: Fun methodologies for engaging children in enlightening adults. Childhood, 14(1), 29-45.

Dahlberg, G., Moss, P. og Pence, A. (2006). Beyond quality in early childhood education and care: Languages of evaluation (2. útgáfa). London og New York: Routledge Falmer.

Dockett, S. og Perry, B. (2011). Researching with young children: Seeking assent. Child Indicators Research, 4(2), 231-247. Sótt af https://link.springer.com/article/10.1007/s12187-010-9084-0

Fane, J., MacDougall, C., Jovanovic, J., Redmond, G. og Gibbs, L. (2018). Exploring the use of emoji as a visual research method for eliciting young children's voices in childhood research. Early Child Development and Care, 188(3), 359-374. doi:10.1080/03004430.2016.1219730

Guðrún Alda Harðardóttir. (2014). Námstcekifori barna í leikskóla: Tekifari leikskólabarna til pátttöku og áhrifa á leikskólanám sitt (doktorsritgerð). Menntavísindasvið Háskóla Íslands, Reykjavík.

Guðrún Kristinsdóttir og Hervör Alma Árnadóttir. (2015). Hliðvörður - hvert er hlutverk pitt? Pátttaka barna í rannsóknum. Netla - Veftímarit um uppeldi og menntun. Sótt af http://netla.hi.is/greinar/2015/ryn/002.pdf

Hrönn Pálmadóttir og Jóhanna Einarsdóttir. (2015).Young children’s views of the role of preschool educators. Early Child Development and Care, 185(9). doi:10.1080/03004430.2015.1004056

Jóhanna Einarsdóttir. (2008). „Við megum ráða pegar við erum búin með bækurnar“: Reynsla barna í 1. bekk grunnskóla. Uppeldi og menntun, 17(2), 9-30.

Jóhanna Einarsdóttir. (2012a). Raddir barna í rannsóknum. Í Jóhanna Einarsdóttir og Bryndís Garðarsdóttir (ritstjórar), Raddir barna (bls. 13-48). Reykjavík: RannUng og Háskólaútgáfan.

Jóhanna Einarsdóttir. (2012b). Minningar úr leikskóla. Í Jóhanna Einarsdóttir og Bryndís Garðarsdóttir (ritstjórar), Raddir barna (bls. 163-178). Reykjavík: RannUng og Háskólaútgáfan.

Kellett, M. (2011). Empowering children and young people as researchers: Overcoming barriers and building capacity. Child Indicators Research, 4(2), 205-219. Sótt af https://link.springer.com/article/10.1007/ s12187-010-9103-1

Kim, C. (2016). Why research by children? Rethinking the assumption underlying the facilitation of children as researchers. Children E Society, 30(3), 230-240. doi:10.1111/chso.12133

Langston, A., Abbott, L., Lewis, V. og Kellett, M. (2004). Early childhood. Í S. Fraser,V. Lewis, S. Ding, M. Kellett og C. Robinson (ritstjórar), Doing research with children and young people (bls. 147-160). London: Sage.

Lenz Taguchi, H. (2010). Going beyond the theory/practice divide in early childhood education: Introducing an intra-active pedagogy. London: Routledge. 
Levy, R. og Thompson, P. (2015). Creating ‘buddy partnerships' with 5- and 11-year old-boys: A methodological approach to conducting participatory research with young children. Journal of Early Childhood Research, 13(2), 137-149. doi:10.1177/1476718X13490297

Lipponen, L., Rajala, A., Hilppö, J. og Paananen, M. (2016). Exploring the foundations of visual methods used in research with children. European Early Childhood Education Research Journal, 24(6), 936-946. doi: 10.1080/1350293X.2015.1062663

Lundy, L. og McEvoy, L. (2012). Children's rights and research processes: Assisting children to (in)formed views. Childhood, 19(1), 129-144. doi:10.1177/0907568211409078

Lög um samning Sameinuðu pjóðanna um réttindi barnsins nr. 19/2013.

MacBlain, S., Dunn, J. og Luke, I. (2017). Contemporary childhood. Los Angeles: Sage.

Menntamálaráđuneytið. (1999). Aðalnámskrá leikskóla. Reykjavík: Höfundur.

Mennta- og menningarmálaráðuneytið. (2011). Aðalnámskrá leikskóla. Reykjavík: Höfundur.

Merewether, J. og Fleet, A. (2014). Seeking children's perspectives: A respectful layered approach. Early Child Development and Care, 184(6), 897-914. doi:10.1080/03004430.2013.829821

Moore, T., Saunders,V. og McArthur, M. (2011). Championing Choice-Lessons Learnedfrom Children and Young People About Researchand Their Involvement. Child Indicators Research, 4(1), 249-267. doi:10.1007/ s12187-010-9083-1

Mukherji, P. og Albon, D. (2010). Research methoods in early childhood. An introductory guide. Los Angeles: Sage.

Nilsson, S., Björkman, B., Almqvist, A., Almqvist, L., Björk-Willén, P., Donohue, D., ... Hvit, S. (2013). Children's voices: Differentiating a child perspective from a child's perspective. Developmental Neurorehabilitation, 18(3), 162-168. doi:10.3109/17518423.2013.801529

Palaiologou, I. (2014). 'Do we hear what children want to say?' Ethical praxis when choosing research tools with children under five. Early Childhood Development and Care, 18(5), 689-705. doi:10.1080/03004430 .2013.809341

Palaiologou, I. (2016). Child observation: A guide for students of early childhood. London: Sage.

Pascal, C. og Bertram, T. (2009). Listening to young citizens: The struggle to make real a participatory paradigm in research with young children. European Early Childhood Education Research Journal, 17(2), 249-262. doi:10.1080/13502930902951486

Rogers, R., Labadie, M. og Pole, K. (2016). Balancing voice and protection in literacy studies with young children. Journal of Early Childhood Literacy, 16(1), 34-59. doi:10.1177/1468798414554632

Samningur Sameinuðu pjóðanna um réttindi barnsins. (1992).

Spyrou, S. (2011). The limits of children's voices: From authenticity to critical, reflective representation. Childhood, 18(2), 155-165. Doi:10.1177/0907568210387834

Stjórnarskrá lýðveldisins Íslands nr. 33/1944.

Waller, T. og Bitou, A. (2011). Research with children: Three challenges for participatory research in early childhood. European Early Childhood Education Research Journal, 19(1), 5-20. doi:10.1080/1350293X .2011.548964? src= recsys

Wright, K. (2015). Are Children Vulnerable in Research? Asian Bioethics Review, 7(2), 201-213.

Yardley, A. C. (2011). Children as experts in their own lives: Reflections on the principles of creative collaboration. Child Indicators Research, 4(2), 191-204. doi:10.1007/s12187-010-9102-2

Änggård, E. (2015). Digital cameras: Agents in research with children. Children's Geographies, 13(1), 1-13.. do i:10.1080/14733285.2013.827871

Anna Elísa Hreiðarsdóttir og Kristín Dýrfjörð. (2019).

Mat leikskólabarna á pátttöku í tilviksrannsókn.

Netla - Veftímarit um uppeldi og menntun. Menntavísindasvið Háskóla Íslands.

Sótt af http://netla.hi.is/serrit/2019/menntun_barna_leik_grunn/02.pdf

DOI: https://doi.org/10.24270/serritnetla.2019.34 